\title{
Hazardous Activities in Hungary - in terms of Industrial Safety
}

\author{
KÁTAI-URBÁN Irina ${ }^{1}$, VASS Gyula²
}

\begin{abstract}
Storage, processing and use of dangerous substances which are present in hazardous activities involve the risk of major accidents. The experience of recent history shows that industrial accidents can cause catastrophic effects to the environment of dangerous industrial establishments and citizens living nearby. The aim of the authors of this article is to categories the Hungarian hazardous activities and provide the readers with a general overview of their vulnerability.
\end{abstract}

Keywords: disaster management, industrial safety, vulnerability, Hungary, hazardous activities.

\section{Preface}

The Hungarian Parliament, in order to improve the safety of the public and of the environment and the efficiency of the prevention of manmade disasters, to strengthen the system of disaster management organizations and to improve the results of emergency actions, by the adoption of Act CXXVIII/2011 on disaster management and on the amendment of individual, related acts (Dis. Man. Act), created on January $1^{\text {st }}$ 2012, a standardized system of authority tasks, organizations and procedures for industrial safety. [1]

The newly enacted industrial safety regulations (the third individual sector beside civil protection and fire prevention) cover the prevention of major accidents involving dangerous substances, and the protection of shipments containing dangerous goods, protection of critical systems and installations and the disaster management tasks of nuclear safety. [2]

In the present article the objective of the authors is to identify the hazard sources relevant for the occurrence of manmade disasters. Their objective is furthermore to typify such hazard sources and then to evaluate the exposure to major dangers in terms of industrial safety. The article is dedicated exclusively to sources of danger (hazardous activities) that are relevant in terms of the application of the law by the disaster management authority and we prepared only a general status report about the present status (June 30, 2013) of the implementation of the legal regulations.

We have used basically the public data (prepared for the general information of the public) provided by the National Directorate General for Disaster Management of the Ministry of the Interior (MI NDGDM), National Chief Inspectorate for Industrial Safety. Furthermore we have used also the specialist literature that is rather limited in this field.

In this article, in a way not yet examined by others, we propose a hazard source classification system based on the industrial safety aspects of manmade disasters. In addition we provide a comprehensive overview about the exposure to hazardous activities in Hungary.

1 kataii@tuzoltosagbp.hu

2 National Directorate General for Disaster Management, Ministry of the Interior 


\section{General classification of activities posing disaster risks}

There are several versions of grouping disasters (hazard sources) known by professionals and scientists. In the legal provisions it is only the implementing regulation of the disaster management act, [3] where there is a split related to effects posing hazards, applied in risk assessment procedures. From the scientific point of view several grouping systems can be identified, however it is common in those systems that disasters are basically assigned to two groups: natural and a manmade group.

In terms of industrial safety, we shall evaluate manmade disasters, major accidents and other events endangering human health and life, the environment and critical assets affecting them. This will be done from the point of view of the disaster management act, "critical system components" covered by the regulations about critical systems and installations or related to "dangerous activities", or the "transportation of dangerous goods".

Dangerous activities are, in the application of the disaster management act, art. $3 \S$. clause 31 "is an activity carried out by using industrial, biological (agricultural), chemical procedures, which, if it becomes uncontrolled, can endanger massively human health, the environment and the safety of life and security." [4]

Hazardous activities (stationary sites) can be classified in terms of industrial safety basically as follows:

- activities related to dangerous substances and goods;

- activities related to hazardous wastes;

- activities related to radioactive materials;

- and hazardous mining activities.

The transportation of hazardous goods (mobile hazard sources) are differentiated in almost all technical literature in Hungary by transportation on public road, by railway, inland waterways and air transport.

Critical systems are defined in Act CLXVI/2012 on the identification, selection and protection of critical systems and installations (hereinafter: Lrtv.) in the explanatory provisions (Lrtv. 1. § clause g) are as follows: "a system component of systems, assets, installation belonging to one of the sectors defined in the annexes 1-3, that are essential for the completion of social tasks, thus in particular for healthcare, for the personal safety and security of the public, for economic and social public services, which, in case of their unavailability, due to the lack of the continuous completion of these tasks would result in major consequences." [5]

Critical system elements can be assigned according to the law to 10 main groups: energy, transportation, agriculture, healthcare, finances, industry, information and communication technologies, water, law and order, government and public safety and defense.

Following the aforementioned concept, on figure No. 1 the principal summarized results of the classification of activities (based on aspects of industrial safety) that pose risks of manmade disasters are illustrated.

Hereinafter we will cover only the general evaluation of the hazards posed by hazardous activities in Hungary. In the present article the transportation of hazardous goods and critical systems and installations are not analyzed. 


\section{Production, storage and processing of hazardous goods}

In the course of major accidents happening during the production, storage, processing of dangerous substances (goods) there can be a fire or explosion and substances harmful to the health and environment might be released into the air or watercourses, thus endangering the public and the environment. The harmful effects of fire and explosions will most probably cause damage in the direct vicinity of dangerous establishments only, harming human health or the environment, within a very short time after the accident. The release of dangerous substances into the air, depending on the type, quantity, physical properties, the meteorological, surface and other conditions, can cause danger several or, in extreme cases, several tens of kilometers far away from the location of the accident. This takes, according to my experience, several tens of minutes, maybe hours. In case of substances with a permanent effect the effects can be long-lasting, occasionally even for decades. [6]

In Hungary, because of the hydrography of the country, dangerous substances can get into watercourses because of incidents, a low technological level of operation or human mistake. The effects of the catastrophic contamination of living waters can last for several days, maybe even several weeks, and the danger can emerge even several hundreds of kilometers far away. As 95\% of the water catchment area of Hungarian rivers is located outside of our borders, in the course of the preparation it is not enough to consider only dangerous industrial establishments located in Hungary.

Explosions happening in the course of major accidents, radiating heat, or burning materials emitted can trigger, within or outside of the establishment, further major accidents (domino effect) and can cause massive panic resulting in major consequences.

From the four main groups of dangerous activities, I have checked the activities involving dangerous substances and dangerous goods in terms of industrial safety first.

In the field of the production (manufacturing) storage and processing of dangerous substances and goods, activities designated as installed establishments can be divided into two main groups.

\section{a) Establishments involving dangerous substances and below tier establishments}

Establishments involving dangerous substances covered by the rules regulating major accident prevention, and so called below tier establishments belong to the first group.

The establishments involving dangerous substances, the so-called "Seveso establishments" mean dangerous activities identified in line with the rules of the Seveso II. Directive.

Based on the definition of the disaster management act, $\S 3$, clause 28, the establishment involving dangerous substances "is the complete area under the management of an operator, where, in one or more installations involving dangerous substances, common or related infrastructure included, there are dangerous substances present in quantities reaching the tier value specified in the legal regulation issued for the implementation of the present act."

Establishments involving dangerous substances can be assigned on the basis of the methodology listed in the implementing regulation, annex 1, to lower and upper tier categories. The basis of categorization is the quantity of dangerous substances at the sites (including also 
materials that will expectedly be produced because of the runaway reaction of the process) and their danger categories [6]. Dangerous substances (chemical agents and formulations) are assigned to danger categories in line with Ac XXV/2000 on chemical safety and the related implementing regulation.

In the implementing regulation, annex 1, table 1 the most frequent dangerous substances and the related lower and upper tier quantities are listed. In table No. 2 the danger categories of dangerous substances and the related lower and upper tier quantities are listed. Dangerous substance is the substance included in table 1 or belonging to any danger class of table 2, and being present in the establishment as raw material, product, semi-finished product, byproduct or wastes. The threshold quantities specified in the tables apply to one establishment.

In case the quantity of the dangerous substances being present in the establishment reaches or exceeds the value specified in column 2, then the establishment is a lower tier establishment, if it reaches or exceeds the values specified in column 3, the establishment is an upper tier establishment.

As of January 1, 2012, in addition to the lower and upper tier establishments involving dangerous substances covered by the Seveso II Directive, the procedures and obligations applying to the operators of below tier establishments have been added. [6].

The new regulation (Dis. man. Act Chapter IV. and its implementing regulations) impose, in addition to the existing regulations, obligations on operators as well, at whose sites there are dangerous substances in quantities exceeding one fourth of the lower tier quantity specified in the regulation but not reaching the lower tier level and on operators of installations that shall be handled with priority.

The sites, where chlorine or ammonia is present in quantities of at least $1,000 \mathrm{~kg}$, where hazardous wastes are neutralized by incineration, and installations used for the transportation of hazardous wastes, dangerous substances beyond the battery limits are also included in this group.

Installations used for the transportation of hazardous goods that are, as a main rule, not covered by the Seveso II. Directive belong to the second group. When regulations were amended in Hungary in the year 2012, the codifier extended the effect of the regulations over establishments involved in the temporary storage of hazardous goods and installations used for the transportation of hazardous goods by pipeline.

However in the practice of the application of law in Hungary switching yards and ports are an exception. As the authority regards switching yards and ports to be part of transportation activity, they are not yet deemed establishments involving dangerous substances. In connection with the modification of disaster management regulations the codifier subjected these activities to authority inspection. However the licensing and supervising activity at dangerous establishments and the application of emergency plans are still missing.

The dangers resulting from the dangerous establishments installed can be most simply demonstrated by the application of a GIS tool (danger map or hazard map).

The Major Accident Hazard Bureau working at the Joint Research Center of the European Commission has prepared, in line with the Seveso II. Directive, Art. 13 on trans-boundary effects, the Seveso Plants Information Retrieval System (SPIRS). "Seveso establishments" can most simply be typed on the basis of the SPIRS system. In the SPIRS system - irrespective of the actual dangers of the dangerous establishment, the danger resulting from lower tier establishments is demonstrated by a circle with a diameter of $2 \mathrm{~km}$, and in case of upper tier establishments by a circle with a diameter of $5 \mathrm{~km}$. [7] 
In the practice of the application of the law in Hungary the elements of SPIRS are integrated into the Industrial Accident Information System (IAIS) of the disaster management authority. IAIS includes, in addition to the Seveso establishments, also the basic data of below tier establishments, like their geographic location (address of the site), their status (lower, upper tier and below tier) or the industrial classification of the dangerous establishment.

Based on the IAIS the establishments producing, processing and storing dangerous substances can be assigned to a total of 17 groups (activities). The activities of the IAIS, because of the characteristics of below tier establishments, are not fully in conformity with the SPIRS classification. The disaster management authority sends a list, address, status and activities of the establishments to the Joint Research Centre of the European Commission every year.

The classification of below tier establishments is identical with that of Seveso establishments, with the difference, that among below tier establishments there are "installations to be handled with priority". In these hazardous activities the $25 \%$ threshold of the lower tier is not considered. The establishments where there is at least $1,000 \mathrm{~kg}$ of chlorine or ammonia present, if these establishments are not establishments dealing with dangerous substances, belong to the group of below tier establishments. The installations used for the transportation of dangerous substances by pipeline are registered as installations used for the transportation of hazardous goods, while installations used for the neutralization of hazardous wastes by incineration are recorded among establishments involving hazardous wastes.

Based on the data of MI NDGDM the number of 169 lower and upper tier establishments covered by the regulations before 2012 increased by 37\% because of the new regulation taking effect. In Hungary, as of July 2013, there are 129 lower tier, 97 upper tier and 509 below tier establishments and 3 more establishments are being constructed. There are further 537 below tier establishments under the effect of the new regulation, and accordingly there are already 758 dangerous establishments covered by the dis. man. act and by its implementing regulation.

The upper tier establishments covered by the agreement of the UN Economic Commission for Europe (UN ECE) about the trans-boundary effects of industrial accidents are located along the Slovakian and Ukrainian border. The number of dangerous activities identified within a $15 \mathrm{~km}$ zone of the state boundary is 9, whereas the number of activities identified in the water catchment areas and endangering Croatia and Serbia is 14 [8] The Hungarian Disaster Management authority is responsible for the implementation of the technical, bilateral and multilateral provisions of the UN ECE international piece of legislation. The technical information provided for the purposes of the bilateral cooperation is written in safety documentation handled in by the operator of the upper tier establishments dealing with dangerous substances. [9]

The next figure illustrates on the basis of the authority records of MI NDGDM the geographical location of establishments involving dangerous substances in Hungary. 


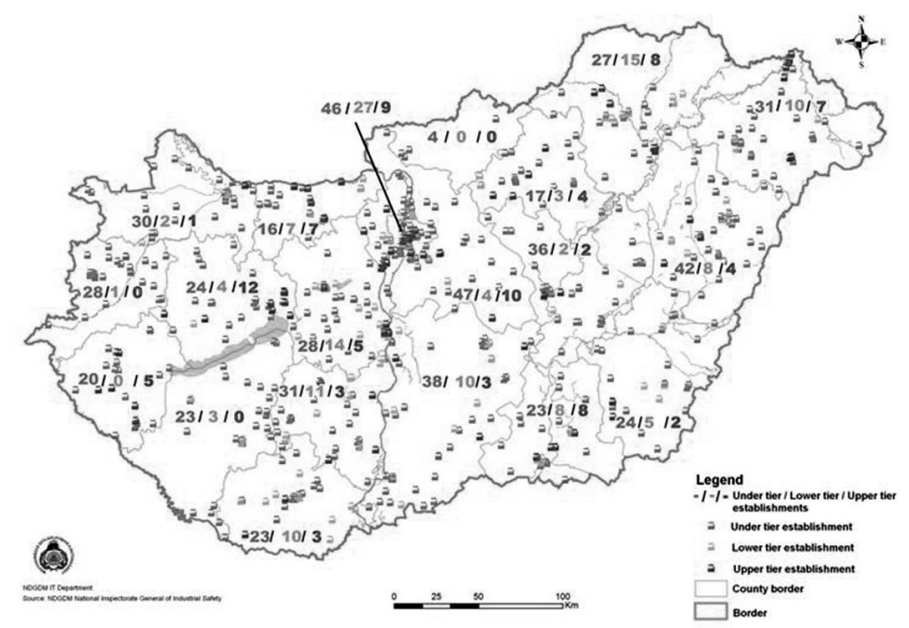

Figure 1. Location of establishments involving dangerous substances and below tier establishments in Hungary (source: MI NDGDM National Chief Inspectorate for Industrial Safety, July 1, 2013.)

\section{b) Installations used for the transportation of hazardous goods}

Installations used for the transportation of hazardous goods can be divided into five groups, in line with the transportation methods, as follows:

- Installations used for the road transportation of hazardous goods

- Installations used for railway transportation;

- Installations used for the transportation over inland waterways;

- installations used for the preparation of air transport;

- Installations used for transportation by pipeline.

Installations used for the road transportation of hazardous goods, that is warehouses used for the storage of hazardous goods in ADR (the European Agreement concerning the International Carriage of Dangerous Goods by Road) packaging, are recorded. Almost all warehouse halls that are of great significance in terms of logistics are located in the agglomeration of Budapest. This is otherwise also logical, as most of the consumption and business life is concentrated in Budapest and in its direct surroundings. From this region the products desired can be transported to any point of the country within 2-3 hours. [10]

Installations used for railway transportation are first of all switching yards that do not belong to the group of establishments involving dangerous substances. These installations shall prepare an internal emergency management plan in line with RID 1.10 and this plan regulates basically the consequence mitigation and prevention rules of the Seveso Directive applied to safety reports. On the basis of the data of MI NDGDM MÁV Zrt. identified a total of 14 yards in the area of Hungary, the most significant ones are the yards in Ferencváros, Miskolc, Szolnok and Záhony. [11]

Another major type of the installation of rail transport is the switching yard and sidings of establishments producing, processing and storing dangerous substances. Switching yards located in the area of establishments involving dangerous substances or in the area of below tier 
establishments or sidings closely related to the sites pose major hazards. Sidings connected to sites can cause individual and significant dangers, as there is a high number of wagons there without any physical protection, without the supervision of the operator and of the authority.

Railway, public road, and trans-shipment facilities can be established dealing with dangerous substances or establishments not classified. The most significant operating establishment is in Budapest (Bilk Kombiterminál Zrt.). During the trans-shipment of containers the fact that the safety of containers arriving at the terminal depends on the variable quality of dispatch in Hungary or abroad and on the technical condition of the wagons is a frequent problem.

Loading and unloading facilities of establishments involving dangerous substances and ports dealing with dangerous substances are registered as installations used for inland waterway transportation. In Hungary there are loading and unloading installations at the petroleum port in Csepel (MOL Csepel base site, and Oil Tanking Kft.), at MOL Plc. Danube Refinery in Százhalombatta and at the site of Lukoil in Dunaföldvár. [12]

In case of the facilities used for the preparation of air transport the warehouses used for the storage of dangerous goods at the airport (Liszt Ferenc Airport) are registered, which cause, due to the relatively low material quantities, no significant danger compared to other transportation methods.

The implementing regulation includes the definition of the transportation of hazardous substances by pipeline (as establishments to be handled with special attention). Transportation pipelines, pump, compressor and distribution stations belong to this group, with the exception of the distribution pipelines used for natural gas supply to the public, and the collection pipelines with a nominal diameter below $400 \mathrm{~mm}$ used for hydrocarbon mining.

\section{Activities dealing with hazardous wastes}

Activities involving hazardous substance temporary storage facilities, used for the storage of hazardous wastes produced at establishments involving hazardous wastes, are listed. There might be hazardous wastes produced in below tier establishments, and in low quantities at a high number of non-classified sites.

The hazardous wastes accumulated in these facilities are assigned to hazardous waste categories on the basis of the environmental regulations and are transported to neutralization plants or to other sites specializing in the preparation and collection of hazardous wastes. The classification of hazardous wastes according to the European Waste Catalogue (EWC) is, based on the KöM (Ministry of Environment) regulation No. 16/2001 (VII. 18.), and is the task and duty of the producer. Classification is influenced also by other objective aspects and interests. If a waste is hazardous or not is determined by the aforementioned KöM regulation, according to the presence of components expressed in \% and characterized by R-phrases. New hazardous wastes or hazardous wastes with unknown composition can be classified on the basis of the composition and hazard parameters. Based on the production technology of wastes (statistical approach), the EWC systemizes wastes in predefined groups. In the technical content of these groups some of the exact physical, chemical and other parameters applied in ADR can be found in exceptional cases only.

Among the neutralization activities, from the point of view of hazards, establishments neutralizing hazardous wastes by incineration are regarded as the most dangerous. 
There is just a low number of hazardous waste incineration plants in Hungary, the most significant ones are in Dorog, Győr, Sajóbábony, Balatonfüred, Tiszaújváros and Tiszavasvár.

Among the activities involving hazardous wastes the ones that are most significant from the point of view of hazards are subject to the regulations about the prevention of major accidents.

One of the unresolved questions of the last decades is environmental safety, and within this the handling of hazardous wastes as independent hazard sources. In Hungary several million of hazardous waste are generated every year. The quantity of industrial wastes and liquid and sludge-like hazardous wastes is decreasing, while the quantity of solid hazardous wastes is increasing.

Some $30 \%$ of the hazardous wastes recorded (based on the calorific value) can be combusted. Other wastes need further treatment, first of all physical, chemical, biological decontamination, whereas unavoidable residues require professional disposal. Some $0.5-0.7 \%$ of domestic solid wastes are hazardous wastes.

In my opinion hazardous wastes are first of all an environmental and health problem and jeopardize mainly the environment, human health is only indirectly endangered. The risk of danger occurs in case of the various environmental elements, usually as permanent environmental pollution.

\section{Activities involving radioactive substances}

Activities dealing with radioactive substances can be divided in terms of industrial safety into two main groups: nuclear installations and isotope laboratories.

\section{a) Nuclear installations}

With regard to the potential risks, among the nuclear installations in Hungary Paksi Atomerőmü Zrt. with its 4 pieces of VVER-440 (Voda Voda Energo Reactor - Water-Water Power Reactor) power generation blocks ranks first. The blocks are arranged in two pairs, in a "hermetic space" protected by a localization tower preventing/delaying release in case of minor/major accidents, respectively.

Next to the reactors, but outside of the hermetic space there are the spent nuclear fuel pools, where the spent fuel is cooled for 5 years before outbound shipment. There are 70 settlements within the $30 \mathrm{~km}$ radius of the power plant. The settlements belong to Tolna, BácsKiskun and Fejér County in terms of public administration. Depending on the emissions and weather conditions, a smaller or larger part of this region might require emergency response. The probability of exposure of regions farther off to danger is low but not nil [12].

The research reactor of the Central Research Institute of Physics (Központi Fizikai Kutatóintézet - KFKI) and the teaching reactor of the Nuclear Technical Institute of the Technical University of Budapest (BME Nukleáris Technikai Intézet) are less significant from the point of view of accidents.

The Temporary Storage of Spent Fuel (Kiégett Kazetták Átmeneti Tárolója — KKÁT) is a separate organization, but it is physically located within the battery limits of the Paks Nuclear Power Plant. The danger of KKÁT is that of accidents during transportation and loading.

Spent fuel is transported since the commissioning of KKÁT, in exceptional cases only, thus the related risk is also low. At the same time the activity of spent fuel is significantly higher and it is harder to localize due to its gamma radiation and requires more expertise. 
Accidents happening during the transportation of highly active isotopes is also similar, where the restoration of the protection of the isotope is the most urgent task. The effect of transportation between the spent fuel pools and KKÁT and of accidents happening here beyond the battery limits is not probable.

The risks resulting from nuclear installations in Hungary can be characterized on the basis of the planning zones applied in response activities following nuclear accidents, as shown in the next table. The individual installations are assigned to hazard planning categories (category $\mathrm{I}-\mathrm{V})$, where

- Zone of Preventive Precautionary Actions (Megelőző Óvintézkedések Zónája MÓZ) in case of installations belonging to the 1st planning category this is a pre-selected area, for which urgent precautionary actions are planned in advance, and the implementation of such actions are ordered immediately after the identification of a General Emergency Situation.

- Zone of Urgent Precautionary Actions (Sürgős Óvintézkedések Zónája — SÓZ) in case of installations belonging to planning category I or II this is a pre-selected area, for which urgent precautionary actions are planned in advance.

- Zone of Foodstuff Consumption Restrictions (Élelmiszerfogyasztási Korlátozások Óvintézkedési Zónája — ÉÓZ) is the area, within which the restriction of the foodstuff consumption of the population, the checking of agricultural producers and of the food processing industry, the strict regulation or restriction of their activities by legal regulations (as needed) becomes necessary. [13].

Table 1. Designation and area of planning zones [13]

\begin{tabular}{|l|c|c|c|}
\hline & MÓZ & SÓZ & ÉÓZ \\
\hline \multicolumn{4}{|c|}{ I. VTK } \\
\hline Paks Nuclear Power Plant & $3 \mathrm{~km}$ & $30 \mathrm{~km}$ & $300 \mathrm{~km}$ \\
\hline \multicolumn{4}{|c|}{ II. VTK } \\
\hline KKÁT & - & - & $3 \mathrm{~km}$ \\
\hline Budapest Research Reactor & - & KFKI site & $1 \mathrm{~km}$ \\
\hline Izotópintézet Kft. & - & KFKI site & $1 \mathrm{~km}$ \\
\hline \multicolumn{4}{|c|}{ III. VTK } \\
\hline BME Teaching Reactor & - & - & - \\
\hline RHFT & - & - & $3 \mathrm{~km}$ \\
\hline NRHT & - & $3 \mathrm{~km}$ \\
\hline \multicolumn{5}{|c|}{ V. VTK } \\
\hline Bohunice & $3 \mathrm{~km}$ & $30 \mathrm{~km}$ & $300 \mathrm{~km}$ \\
\hline Mohovce & $3 \mathrm{~km}$ & $30 \mathrm{~km}$ & $300 \mathrm{~km}$ \\
\hline Krsko & $3 \mathrm{~km}$ & $30 \mathrm{~km}$ & $300 \mathrm{~km}$ \\
\hline Dukovany & $3 \mathrm{~km}$ & $30 \mathrm{~km}$ & $300 \mathrm{~km}$ \\
\hline Temelin & $3 \mathrm{~km}$ & $30 \mathrm{~km}$ & $300 \mathrm{~km}$ \\
\hline
\end{tabular}

The data of the table above expressed in figures are visualized on the following figure also as a map. 


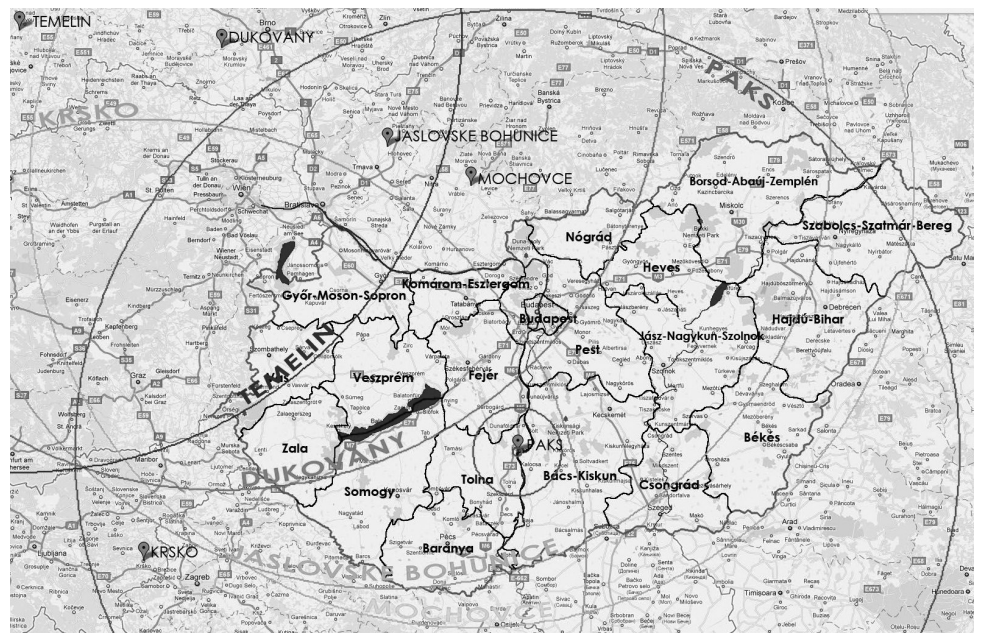

Figure No 2. Nuclear hazards in Hungary [13]

There is a Preventive Precautionary Zone marked in Hungary around the Paks Nuclear Power Plant only, this is an area with a radius of $3 \mathrm{~km}$. There is also an Urgent Precautionary Zone marked in Hungary around the Paks Nuclear Power Plant only, this is an area with a radius of $30 \mathrm{~km}$ and the KFKI site that includes the Budapest Research Reactor.

The circles with a radius of $300 \mathrm{~km}$ around the Paks Nuclear Power Plant and around foreign nuclear power plants, that is the Precautionary Zone of Food Consumption Restrictions cover practically the whole area of Hungary, only small areas east from the line Vásárosnamény-Mátészalka are not affected by this zone.

Due to the location of nuclear power plants abroad their marked Preventive and Precautionary Zones do not reach Hungary [13].

\section{b) Facilities producing radioactive materials (isotopes)}

Based on the data of MI NDGDM 3 of the facilities producing radioactive substances (isotopes) are in Budapest and two are in Debrecen. Radioisotope is being produced in the experimental nuclear reactor of the Nuclear Energy Research Institute (Atomenergia Kutató Intézet), while the Institute of Isotopes Co., Ltd. (Izotóp Intézet Kft.) produces iodine radiation source. PET (Positron emission tomography) radioisotope is being produced in a medical cyclotron by the University of Debrecen (Debreceni Egyetem) Medical and Health Science Centre (OEC — Orvos- és Egészségtudományi Centrum) Nuclear Medicine Institute (Nukleáris Medicina Intézet) in Debrecen and by Pozitron Diagnosztikai Kft. in Budapest. Medical and industrial radioisotope is being produced by MTA ATOMKI (Atommagkutató Intézet - Institute for Nuclear Research) (MGC-20E cyclotron) at their site in Debrecen.

Based on the data of MI NDGDM there are a total of 33 pieces of " $\mathrm{B}$ " and " $\mathrm{C}$ " category isotope laboratories with no patients working in the country, which pose only limited danger to their environment in terms of disaster management.

The aspects used for the civil defense classification of isotope laboratories depend mainly on the classification of the laboratory (A, B, C levels), and on the category of importance of 
the installation (priority, I., II., III. category). In addition to the aforementioned aspects the factors of the activities of laboratories dealing with radioactive substances posing a risk to the public influence the classification as well. The EüM (Ministry of Health) regulation No. 16/2000 (VI. 8.) on the implementation of the Nuclear Energy Act No. 1996/CXVI. includes detailed provisions about the aforementioned point.

With regard to the civil defense classification, the establishment of adequate safety systems in laboratories that frequently work with volatile, gas- and steam phase radioactive isotopes with long half-life period, and with toxic radioactive isotopes with long half-time period, and the regular inspection of such laboratories, combined with environmental sampling is highly important.

In addition to radioactivity measurements, in justified cases, the inspection shall be carried out by sampling and by radioactivity analytics, chemical, biological measurement carried out in special laboratories. The frequency of the authority inspections at isotope laboratories is properly described in the regulation 16/2000 (VI.8.) EüM, Annex 7.

\section{Hazardous mining activities}

\section{a) Mining activities}

We have anticipated that in the field of hydrocarbon production, the mining of crude oil and natural gas, the primary processing of the raw material takes place still within the battery limits of the mine. In the course of the processing of the produced and imported hydrocarbons intermediate products; fuels and lubricants; and the byproducts of processing (e.g.: bitumen) are produced. Most of the substances are highly flammable and explosive, and can cause major industrial accidents, disasters and environmental disasters.

In the course of the extraction and processing of hydrocarbons the following dangerous situations might arise:

- danger and environmental damage caused by unexpected bursts during the extraction of crude oil and natural gas, and exploratory drills;

- fire or explosion, environmental damage during the storage or primary processing of the extracted crude oil and natural gas in the area of the mine;

- fire or explosion, or environmental damage caused during the processing and storage of imported and extracted crude oil (crude oil refining, production of secondary products (PB gas);

- fire and explosion, environmental damage during storing and logistic activities (product pipeline).

Major crude oil fields are in Algyő and the oil field in North and South Zala.

There are major natural gas fields in Jász-Nagykun-Szolnok, Hajdú-Bihar and Zala County.

There are some 700 exploratory and extraction wells, MOL Plc. carries out crude oil and natural gas extraction activities at 5 mining plants, and six business organizations specialize in crude oil exploration. In Zala, in the course of crude oil extraction the danger of fire and explosion, and the potential release of carbon dioxide used in high quantities can be anticipated. Toxic gases that are harmful to human health (H2S) that are heavier than air and that are released in a mixed condition, can jeopardize several settlements and several thousands of 
people for several days due to the local relief conditions and in case of unfavorable weather conditions. The extracted crude oil and natural gas and significant quantities of the PB gas produced are stored in 5 underground gas storage containers (e.g. gas storage in Pusztaedecser in Zala) at 8 PB gas filling sites and in above-ground facilities (e.g. PB gas storage in Algyő - 30,000 $\mathrm{m}^{3}$ ). Among the industrial plants processing crude oil the white and black storage capacities of the Danube, Tisza and Zalaegerszeg refineries are significant.

The danger related to hydrocarbon transportation pipelines is covered in the subchapter "Transportation of hazardous goods", but due to its nature it shall be mentioned here. In case of transportation pipelines the starting and relay stations and process installations used for operation (e.g. pressure booster, loading, unloading etc. stations) pose major hazards. The exposure to dangers results mainly from above-ground installations, where the accidents and disasters described in the chapter about dangerous industrial installations might happen.

Coal and lignite mining pose no special hazard in terms of industrial safety. The facilities used for the storage of crude oil drilling mud considered hazardous waste can pose a danger to the environment [13].

\section{b) Facilities used for the storage of mining wastes}

According to the records of the NDGDM there are 400 facilities for the storage of mining wastes in Hungary and most of them are not classified. The total number of qualified " $A$ " type facilities is 12 pieces. Some storage sites e.g.: the red sludge storage in Ajka are split into several cassettes. The disaster management authority pays special attention to the safety of facilities used for the storage of mining wastes following the industrial disaster in Kolontár.

In connection with the dam break of the red sludge reservoir on October 4, 2010 in Kolontár the Environmental Chief Inspectorate of the European Commission (EiB) sent an official notice on October 22, 2010 regarding the disaster at the site of MAL Zrt. in Ajka.

EiB asked for information among others on the classification under 96/82/EC Council Directive (Seveso II.) about the inspection of hazards of major accidents related to dangerous substances.

With regard to the applicability of the Seveso II. Directive the European Commission accepted in its reply the standpoint of MI NDGDM, as Hungarian authority, namely that the red sludge and sodium hydrate do not qualify as dangerous substances under the Seveso II, thus the installation is not covered by the Directive.

The first step in Hungary in the elimination of deficiencies affecting environmental and mining law identified and complained about by the European Commission was the amendment of regulations in Hungary regarding mining wastes. In the topic of mining wastes the Hungarian Parliament has adopted Act CLXXXI/2010 on the amendment of individual energy acts and of Act LXXVIII/1997 on the alteration and protection of the built-in environment. According to the law, the Mining Act No. XLVIII/1993 was amended as of January 1, 2011. Certain parts of the amendments were aimed at the conformity with the Directive No. 2006/21/ EC (March 15, 2006), namely the treatment of wastes produced in the mining of minerals.

Accordingly the effect of Act No. XLVIII/1993 covers mining wastes (wastes produced during mining and red sludge produced during the processing of bauxite).

The competence of the Mine Inspectorate was extended by authority procedures related to the management of mining wastes and to the construction, commissioning and operation, 
closing and aftercare of related facilities and installations. Resulting from the change of the legal regulations, the regulation No. 267/2006 (XII. 20.) on the Hungarian Office for Mining and Geology has been amended, and this allows the disaster management authority to participate, as specialized authority, in the construction and occupancy licensing procedure to check the internal emergency management plan. With the amendment of the GKM (Ministry of Economy and Transport) regulation No. 14/2008 (IV. 3.) GKM the regional organizations of MI NDGDM will prepare, revise, along with the mayors of the settlements concerned, the external emergency plans serving for the protection of the settlements and have them drilled.

With the modification of the regulation of mining rights, with the introduction of external emergency response actions, there is a possibility to manage the coordinated activities of disaster management, and of the state and municipal organizations involved in the rescue and emergency response.

Facilities used for the storage of mining wastes can be divided into two main groups: (1) sludge reservoirs and sludge settlement ponds and (2) pit-heaps and soil depots.

Sludge reservoirs are divided into four main groups according to the raw material extracted: (1) red sludge reservoirs (2) spent nuclear fuel storages (3) non-ferrous sludge reservoirs and (4) iron ore sludge reservoirs. The wastes produced in the course of coal and lignite mining are stored on pit-heaps and on soil depots.

\section{Conclusions}

In the article the dangers resulting from hazardous activities in Hungary covered by industrial safety regulations, being part of disaster management have been generally analyzed.

The evaluation of the activities in Hungary that pose risks of disaster, based on the aspects of industrial safety can essentially be found in case of establishments involving dangerous substances only, where dangerous establishments have maps illustrating the individual risk of fatalities and the hazard zones of establishments will be integrated into the land-use plans.

The data base of MI NDGDM (IBIR — Információ Biztonsági Irányítási Rendszer; Information Security Management System) offers adequate possibilities for the extraction of statistical data. The data of authority work are included in the so called Authority Data Base (Hatósági Adatbázis, HADAR) not connected to the IBIR. The hazard sources are visualized as a map in the GIS data base of the NDGDM, however there is no direct data base connection. The results of the hazard analyses are available for each establishment in the safety documentation, however the maps applied there are not standardized. The data of events related to industrial safety are also separately recorded, and these records shall continuously be updated to prepare executive summaries and reports.

With regard to sludge reservoirs and isotope laboratories there is a separate registration not linked to central data bases.

In terms of nuclear hazards we are aware of precautionary action zones established empirically. These zones are visualized on maps as well.

All in all it can be established that most of the activities covered by industrial safety regulations in Hungary are visualized on so-called hazard maps, where data can be analyzed as to the main parameters and location of the hazard source. The danger maps corresponding to the quantitative risk criteria are available for the establishments involving dangerous substances, but at the present they are not visualized on the GIS platform. 
The identification of activities that pose risks of manmade disasters (hazard identification), the creation of standardized data bases, the completion of hazard analyses, the visualization of the results on maps are the continuous task of disaster management organizations. It is possible to develop mainly by bundling the authority and professional data bases and by standardized data handling. The use of GIS shall be given priority in this activity.

\section{References}

[1] KOSSA Gy.: Industrial Safety - Tasks and Challenges in the Deference of Future. (Iparbiztonság — feladatok és kihívások a jövő védelmében. Védelem-Katasztrófa-Tüz-és Polgári Védelmi Szemle 186 (2011), 49-50.

[2] BOGNÁR B., KÁTAI-URBÁN L., KOSSA Gy., KOZMA S., SZAKÁL B., VASS Gy., KÁTAI-URBÁN L. (Ed.): Industrial Safety I. Handbook on Implementation's Tasks of Operators and Authorities. (Iparbiztonságtan I.: Kézikönyv az iparbiztonsági üzemeltetői és hatósági feladatok ellátásához). Budapest: Nemzeti Közszolgálati és Tankönyvkiadó, 2013. ISBN 9786155344121

[3] Government regulation No. 234/2011 (XI. 10.) on the implementation of Act No. CXXVIII. /2011 on disaster management and on the amendment of the related individual acts.

[4] Act 2011 CXXVIII. on disaster management and on the amendment of individual, related acts.

[5] Act No. CLXVI./2012 on the identification of critical systems and installations, their selection and protection.

[6] KÁTAI-URBÁN L., RÉVAI R.: Possible Effects of Disasters Involving Dangerous Substances Harmful to the Environment, Human Life and Health. (A veszélyes anyagokkal kapcsolatos katasztrófák lehetséges környezetet, emberi életet és egészséget károsító hatásai.) Bolyai Szemle, XXII 2 (2013), 151-158.

[7] SZAKÁL B., CIMER Zs., KÁTAI-URBÁN L., VASS Gy.: Industrial Safety II. Consequences and Risks of Major Accidents involving Dangerous Substances. (Iparbiztonság II.: A veszélyes anyagokkal kapcsolatos súlyos balesetek következményei és kockázatai.) Budapest: TERC Kereskedelmi és Szolgáltató Kft., 2013. ISBN 9786155445002

[8] Country Report on the Implementation of UN ECE Convention of Transboundary Effects of Industrial Accidents. (Országjelentés az ipari balesetek országhatáron túli hatásairól szóló ENSZ EGB egyezmény magyarországi alkalmazásáról), Budapest: MI NDGDM, 2012.

[9] KÁTAI-URBÁN L., VASS Gy.: Possible Content of the Information Required by the Provisions of the UN ECE Industrial Accident Convention. (Ipari baleseti ENSZ EGB egyezmény előírásai szerinti adatszolgáltatás lehetséges tartalma.) Bolyai Szemle, XXII 3 (2013), 115-126.

[10] KÁTAI-URBÁN L., SZABÓ Á.: Activities of Dangerous Goods Logistics Sector in Hungary. (Veszélyes áru raktárlogisztikai szektor tevékenysége Magyarországon.) Bolyai Szemle XXII 3 (2013), 227-235.

[11] HORVÁTH H., KÁTAI-URBÁN L.: Assessment of the Implementation Practice of Emergency Planning Regulations Dedicated to the Rail Transportation of Dangerous Goods. Academic And Applied Research in Military Science 121 (2013) 73-82.

[12] KÁTAI-URBÁN L., VASS Gy.: Development of Hungarian System for Protection against Industrial Accidents. In. Jozef Ristvej (Ed.) 18. medzinárodná vedecká konferencia Riešenie krízových situácií v špecifickom prostredí. 2013. 06. 05-06. Zilina: University of Zilina, 229-239. ISBN 9788055406992

[13] National Report on Disaster Risk Assessment, National Directorate General for Disaster Management MoI. (Nemzeti Katasztrófakockázat Értékelés. BM Országos Katasztrófavédelmi Főigazgatóság,) Budapest 2011. 